\title{
Factors influencing the economic mechanism of the development of small and medium-sized dairy cattle breeding enterprises
}

\author{
Olga Rubaeva ${ }^{l}$ and Ekaterina Kachurina ${ }^{2 *}$ \\ ${ }^{1}$ Federal State Budgetary Educational Institution of Higher Education "South Ural State Agrarian \\ University" 75 Lenin Avenue, 454080 Chelyabinsk, Russian Federation \\ ${ }^{2}$ Federal State Budgetary Educational Institution of Higher Education "Financial University under the \\ Government of the Russian Federation”, Ural Branch 58 Rabotnits St., 454084 Chelyabinsk, Russian
}

\begin{abstract}
This article includes analysis of factors influencing economic mechanism for the development of small and medium-sized enterprises in the area of dairy farming. To accomplish the main task, the authors used economic parameters of the production results of small and medium-sized enterprises according to the financial statements of federal and regional government bodies, as well as official data from the Central Bank of Russia, the Territorial Authority of the Federal State Statistics Service for the Chelyabinsk Region and data from the Ministry of Agriculture and Federal Tax Service. The Chelyabinsk Region was chosen as a typical region for study. This research was conducted based on data from the register of small and medium-sized enterprises. Based on statistical data, small and medium-sized enterprises were divided into groups, economic parameters were calculated for each group of subjects, quantitative factors were defined that have the greatest impact on the efficiency of the economic mechanism for the development of small and medium-sized enterprises.
\end{abstract}

\section{Introduction}

The state and prospects of development of small and medium-sized businesses in the dairy farming sector of the agro-industrial complex are one of the main levers of the development of the domestic economy. Small and medium-sized businesses can be created in any sector of the economy, but their presence in the dairy industry contributes to ensuring food security and increasing the welfare of the country's population. Analysis of the works of Russian and foreign scientists has shown that the issues of factors affecting the economic mechanism of small and medium-sized businesses in the dairy sector of animal husbandry remain insufficiently studied.

\footnotetext{
* Corresponding author: mikhalkina-ep@mail.ru
} 


\section{Materials and methods}

For studying the influence of factors on the economic mechanism for the development of small and medium-sized dairy cattle breeding enterprises, statistical and economic and mathematical methods of research were used. These methods allow finding weaknesses in the implementation of the economic mechanism for the development of small and mediumsized enterprises in the area of dairy farming.

Analysis of statistical data showed that for the period from 2010 to 2018 there are negative changes in milk production by regional farms of all categories (Figure 1).

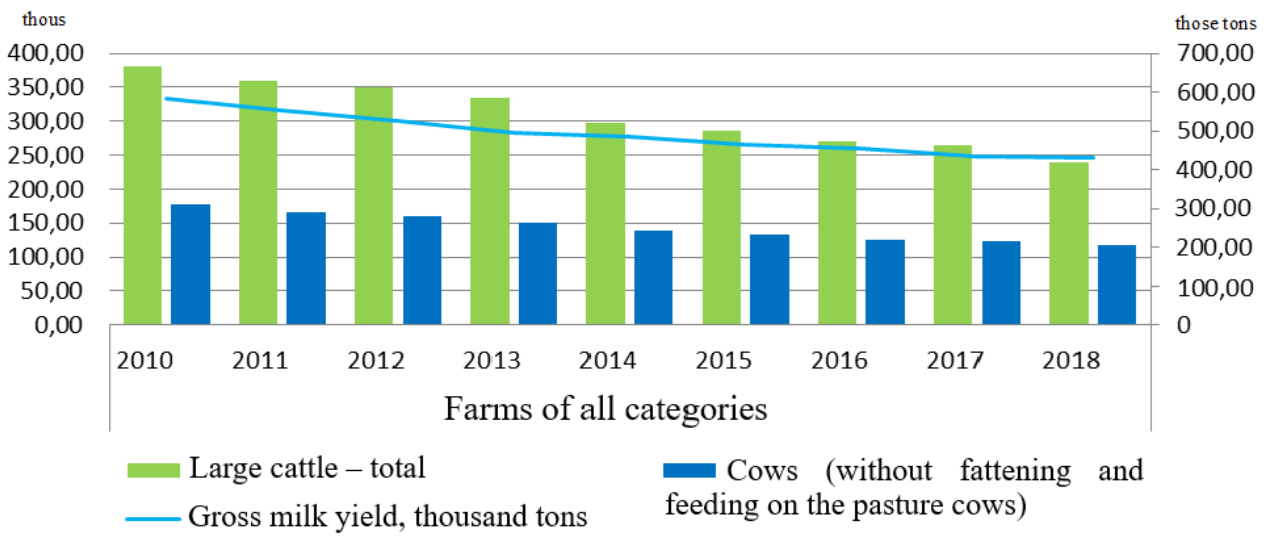

Fig. 1. Milk production in the Chelyabinsk Region $[2,3]$

According to the Registrer of small and medium-sized businesses, in the dairy farming of the Chelyabinsk region, sole proprietors and farmers belonging to the category of microenterprises predominate.

Analysis of statistical data showed that in the existing institutional structure, microenterprises with the organizational form of IE or PFH have the main share among small and medium-sized enterprises producing cow's raw milk. However, practical analysis revealed that the production of dairy products in the Chelyabinsk Region is carried out by large and medium-sized enterprises operating both on their own-produced raw materials and on raw materials purchased from local suppliers, as well as imported from other regions and countries (for example, Belarus). Thus, presence in institutional structure of the predominant share of small and microenterprises does not meet regional demand for raw milk.

Current situation can be explained by the fact that over the past 10 years the number of large cattle in regional agricultural organizations was decreasing, and there was just slight increase in PFHs.

Analysis of theory and practice allows the authors to define general factors and their elements that influence the economic mechanism for the development of small and medium-sized enterprises in the sphere of dairy farming (Table 1).

Table 1. Factors influencing the economic mechanism for the development of small and medium-sized enterprises in AIC

\begin{tabular}{|l|l|}
\hline General group & Elements \\
\hline Economic & $\begin{array}{l}\text { 1. Development of programs for subsidies and preferential loans and their } \\
\text { accessibility for small and medium-sized dairy cattle breeding enterprises }\end{array}$ \\
& 2. Partial compensation by the state of the costs to raw milk producers \\
& 3. Tax rates for small and medium-sized agricultural producers \\
\hline
\end{tabular}




\begin{tabular}{|l|l|}
\hline & $\begin{array}{l}\text { 4. Amount of insurance rates } \\
\text { 5. Specialization and concentration of production }\end{array}$ \\
\hline Organizational & $\begin{array}{l}\text { 1. Infrastructure: transport accessibility, road condition, available access to } \\
\text { high-quality energy and water resources, provision with labor resources, } \\
\text { etc. } \\
\text { 2. Prospects for implementation of innovative technologies for dairy } \\
\text { farming; } \\
\text { 3. Organization of production and sales of products. }\end{array}$ \\
\hline Legal & $\begin{array}{l}\text { 1. Protection of interests of small agricultural producers, including } \\
\text { regulation of purchase prices. }\end{array}$ \\
\hline Information & $\begin{array}{l}\text { 1. Organization of information sharing for economic entities of small and } \\
\text { medium-sized enterprises } \\
\text { 2. Organization of advertising campaign for own-produced products }\end{array}$ \\
\hline Technical and & $\begin{array}{l}\text { 1. Production mechanization and automation } \\
\text { 2. Ability to create and share the best technologies }\end{array}$ \\
\hline Macroeconomic & $\begin{array}{l}\text { 1. Development of the market for domestic agricultural products } \\
\text { 2. Exchange of experience and technologies } \\
\text { 3. Possibility of acquiring high-quality gene pool for further use for } \\
\text { domestic production } \\
\text { 4. World sanctions on domestic goods }\end{array}$ \\
\hline Social & $\begin{array}{l}\text { 1. Workplaces in enterprises } \\
\text { 2. Qualified staff } \\
\text { 3. Level of income of rural population } \\
\text { 4. Popularization of living and working in agricultural regions }\end{array}$ \\
\hline 1. State policy in the field of dairy cattle breeding development \\
\hline Ecological
\end{tabular}

Developed by the authors

Main factors holding back the development of dairy farming in large business are long payback periods and low profitability of dairy products relative to other agricultural activities, however, government support is oriented more on medium-sized and large enterprises . But the analysis of statistical data showed that it is reasonable to divide small and medium-sized enterprises in groups according to their livestock in order to make a qualitative assessment of the influence of factors on the economic mechanism for the development of small and medium-sized dairy cattle breeding enterprises.

Table 2. Effect of the concentration of cow livestock on the efficiency of small and medium-sized enterprises in the Chelyabinsk Region

\begin{tabular}{|l|l|l|l|l|l|}
\hline \multirow{2}{*}{ Parameters } & \multicolumn{5}{l}{ Parameter value } \\
\cline { 2 - 7 } & 2014 & 2015 & 2016 & 2017 & 2018 \\
\hline farms with livestock under 200 animals \\
\hline Milk yield per 1 cow, kg & 4,112 & 4,839 & 6,140 & 6,900 & 7,300 \\
\hline $\begin{array}{l}\text { Cost of fixed assets, thousand RUR } \\
\text { Revenue from sales, thousand } \\
\text { RUR/year }\end{array}$ & 2,454 & 3,548 & 359 & 4,260 & 5,127 \\
\hline Cost, thousand RUR/year & 8,220 & 9,200 & 9,147 & 9,494 & 9,850 \\
\hline Selling price RUR/L level including & 8,154 & 9,384 & 9,101 & 9,158 & 9,411 \\
\hline Profit (loss), thousand RUR & 18 & 20 & 21 & 24 & 23 \\
\hline $\begin{array}{l}\text { Profitability } \\
\text { subsidies,\% } \%\end{array}$ & 5.12 & X & 6.87 & 6.71 & 5.7 \\
\hline Yield per unit of assets & 0.30 & 0.39 & 0.04 & 0.45 & 0.52 \\
\hline Return on assets & 5.83 & -1.86 & 0.57 & 6.69 & 9.13 \\
\hline
\end{tabular}




\begin{tabular}{|c|c|c|c|c|c|}
\hline \multicolumn{6}{|c|}{ farms with livestock from 201 to 700 animals } \\
\hline Milk yield per 1 cow, $\mathrm{kg}$ & 4,723 & 5,710 & 6,418 & 7,801 & 7,590 \\
\hline Cost of fixed assets, thousand RUR & 55,132 & 56,147 & 55,374 & 52,504 & 55,267 \\
\hline $\begin{array}{llll}\text { Revenue } & \text { from } & \text { sales, } & \text { thousand } \\
\text { RUR/year } & & & \\
\end{array}$ & 82,733 & 91,155 & 110,949 & 133,348 & 133,327 \\
\hline Cost, thousand RUR/year & 84,493 & 99,938 & 103,943 & 128,372 & 132,850 \\
\hline Selling price RUR/L & 18 & 20 & 21 & 24 & 23 \\
\hline Profit (loss), thousand RUR & 2,581 & $-4,275$ & 15,389 & 14,282 & 10,266 \\
\hline $\begin{array}{lll}\begin{array}{l}\text { Profitability } \\
\text { subsidies, } \%\end{array} & \text { level } & \text { including } \\
\end{array}$ & 3.12 & $\mathrm{X}$ & 13.87 & 10.71 & 7.7 \\
\hline Yield per unit of assets & 0.67 & 0.62 & 0.50 & 0.39 & 0.41 \\
\hline Return on assets & 21.36 & $\mathrm{x}$ & 3.60 & 3.68 & 5.38 \\
\hline \multicolumn{6}{|l|}{ farms with livestock over 700 animals } \\
\hline Milk yield per 1 cow, $\mathrm{kg}$ & 4,612 & 5,715 & 6,259 & 7,205 & 7,614 \\
\hline Cost of fixed assets, thousand RUR & 559,074 & 699,651 & 760,120 & 677,050 & 794,002 \\
\hline $\begin{array}{llll}\text { Revenue from } & \text { sales, thousand } \\
\text { RUR/year } & & & \\
\end{array}$ & 351,927 & 342,036 & 529,981 & 563,162 & 723,787 \\
\hline Cost, thousand RUR/year & 204,270 & 243,731 & 386,540 & 405,450 & 509,505 \\
\hline Selling price RUR/L & 18 & 20 & 21 & 24 & 23 \\
\hline Profit (loss), thousand RUR & 116,769 & 164,451 & 140,286 & 174,411 & 168,353 \\
\hline $\begin{array}{lll}\begin{array}{l}\text { Profitability } \\
\text { subsidies, } \%\end{array} & \text { level } & \text { including } \\
\end{array}$ & 33.18 & 48.08 & 26.47 & 30.97 & 23.26 \\
\hline Yield per unit of assets & 0.63 & 0.49 & 0.70 & 0.83 & 0.91 \\
\hline Return on assets & 0.21 & 0.24 & 0.18 & 0.26 & 0.21 \\
\hline
\end{tabular}

Developed and calculated by the authors based on sources $[2,3,4]$

When analyzing the influence of the concentration of cow livestock on the efficiency of the economic mechanism of small and medium-sized enterprises in the Chelyabinsk Region, subjects were divided into three groups. The most profitable farms are concentrated in the third group with a livestock of more than 700 animals. Average annual cost share in the revenue of this group of entities is $65 \%$, while in smaller productions this cost can reach $98 \%$ of revenue. Thus, the superiority of large production over small one is obvious. However, production concentration is an important, but not the only factor that has an effect on the effectiveness of the economic mechanism for the development of small and medium-sized enterprises.

Comparative analysis revealed that the share of agriculture in total loan provision is small and, according to the Central Bank of Russia, over the past 10 years it has increased from 1.45 to $2.70 \%$ of total loans to small and medium-sized enterprises.

Practical analysis revealed that preferential loans and subsidizing in the sphere of dairy cattle breeding are more accessible for medium-sized and large enterprises. According to the List of borrowers applying for preferential short-term loans and preferential investment loans - according to which the Russian Ministry of Agriculture made a positive decision to include in the List of borrowers - 21 entities in the sphere of dairy cattle breeding on the territory of Chelyabinsk Region were included in this List from January 23, 2019 to January 15,2020 . It should be mentioned that none of the 21 entities was a small business. Most of approved loans are loans with a term of up to 1 year (Table 3) $[1,4,5]$.

Table 3. Characteristics of the criteria for preferential short-term loans and preferential investment loans according to which the Ministry of Agriculture of Russia made a positive decision to include in the List of borrowers from January 23, 2019 to January 15, 2020 (Chelyabinsk Region) 


\begin{tabular}{|l|l|l|}
\hline Parameter & Estimated value & Units of measurement \\
\hline $\begin{array}{l}\text { Loan amount for all areas of } \\
\text { activity }\end{array}$ & $11,531,941,050.45$ & RUR \\
\hline $\begin{array}{l}\text { Subsidy amount for all areas of } \\
\text { activity }\end{array}$ & $274,797,293.61$ & RUR \\
\hline $\begin{array}{l}\text { Loan amount for dairy cattle } \\
\text { breeding }\end{array}$ & $1,357,970,000.00 / 11.78$ & RUR/\% \\
\hline $\begin{array}{l}\text { Subsidy amount for dairy cattle } \\
\text { breeding }\end{array}$ & $30,608,371.15 / 11.14$ & RUR/\% \\
\hline Number of borrowers & 21 & pcs \\
\hline including small businesses & $0 / 0$ & pcs/\% \\
\hline $\begin{array}{l}\text { subjects of medium-sized } \\
\text { and large businesses }\end{array}$ & $21 / 100$ & pcs/\% \\
\hline Number of loans with a loan term: & 90.48 & $\%$ \\
\hline up to 1 year & 9.52 & $\%$ \\
\hline from 2 to 15 years & \\
\hline
\end{tabular}

However, scale and amount of loans and subsidies are significant, but not the only factors influencing the economic mechanism of small and medium-sized enterprises. The greater the subsidy for increasing productivity in dairy cattle breeding and for the production and sales of market milk and the amount of partial reimbursement of the interest rate on investment loans for the development of livestock, processing of its products, development of infrastructure and logistics for livestock markets, the higher the profitability of enterprise.

\section{Results and discussion}

Based on the results of this study, the authors made the following conclusions:

- growth of profitability of small and medium-sized enterprises from the group with livestock of under 200 animals is influenced by the growth in government subsidies and lowering agricultural insurance costs. It should be noted that programs for subsidizing and preferential loans to small and medium-sized enterprises in dairy farming are actively implemented in the Chelyabinsk Region but the analysis reveals that such parameters as volume of partial reimbursement of the costs of agricultural producers for paying the insurance accrued under the agricultural insurance contract in the field of animal husbandry and weighted average interest rates on loans granted by credit institutions to small and medium-sized business in RUR, from 1 to 3 years, have little effect on profitability level. This fact indicates that it is government subsidy that is the most promising source of funding this type of subjects, as bank loans programs are not fully available for this group of small and medium-sized enterprises.

- growth of profitability of small and medium-sized enterprises from a group with livestock from 201 to 700 animals is influenced by the growth of partial reimbursement of interest rate on short-term loans for the development of livestock production, processing and sales of livestock products and the growth of subsidies for increasing productivity in dairy cattle breeding and the production and sales of market milk; as well as by reduction in average interest rate on loans granted by credit organizations to small and medium-sized enterprises in RUR, from 1 to 3 years, and the cost of insurance tariffs for agricultural insurance with state support. Results obtained for this group of subjects show the need to develop programs for this group related to both preferential bank loans and direct government subsidies.

- growth of profitability of small and medium-sized enterprises from a group with livestock over 700 animals is influenced by the growth of partial reimbursement of interest 
rate on investment loans for the development of livestock production, processing of its products, development of infrastructure and logistics for livestock production markets and the amount of subsidies for increasing productivity in dairy cattle breeding and the production and sales of market milk, as well as reducing the cost of paying insurance tariffs on agricultural insurance with state support, and the amount of calculated fixed agricultural tax.

\section{Conclusions}

The authors found that the development of small and medium-sized dairy farming enterprises is influenced by a huge number of different factors, and not all of them have a positive effect. This fact requires detailed approach and important decisions in this area. Such decisions include development of the system of measures to improve reproduction, personnel, tax, credit, pricing, investment, innovation policies and other areas [7-9].

In order to increase the efficiency of small and medium-sized dairy farming enterprises and based on an analysis of factors having an effect on this process, the authors proposed the following organizational measures for federal and local levels of government, as well as for small and medium-sized enterprises:

1. regular monitoring of key economic parameters in order to define actual situation in the industry and to be able to regulate the influence of different factors.

2. development of technological and technical, transport, financial infrastructure.

3. expanding sales markets and possibility for small suppliers to sell their products to large processing enterprises and distribution networks.

\section{REFERENCES}

1. [Electronic source] URL http://www.cbr.ru

2. [Electronic source] URL http://www.gks.ru

3. [Electronic source] URL http://www.chelagro.ru

4. [Electronic source] URL http://www.nalog.ru

5. Garant legal information database URL: http://www.garant.ru.

6. Decree of the Government of the Russian Federation No. 1528 (as amended on April 26, 2019) as of December 29, 2016 "On the Approval of the Rules for the Provision of Subsidies from the Federal Budget to Russian Credit Organizations, International Financial Organizations and "Bank for Development and Foreign Economic Affairs (Vnesheconombank)" State Corporation", Russia

7. A.N., Syomin, O.N., Mikhaylyuk, Z.T. Vakhitova, Small forms of agribusiness (functioning conditions and new opportunities), 182 (Moscow, 2018)

8. B. Voronin, N. Potekhin, I. Chupina, V. Sharapova, E. Kot, I.V. Razorvin, A. Mokronosov, J. Lysenko, Journal of Environmental Management and Tourism, 8 (32), 1799-1804 (2018)

9. V.I. Chinarov, N.I. Strekozov, N.M. Morozov, S.G. Litvinyuk, Economics of agricultural and processing enterprises (3), 17-20 (2014) 